\title{
Palpable Masses Sequence Number
}

National Cancer Institute

\section{Source}

National Cancer Institute. Palpable Masses Sequence Number. NCI Thesaurus. Code C119914.

An identifier that describes the relative position of palpable masses data within a series. 